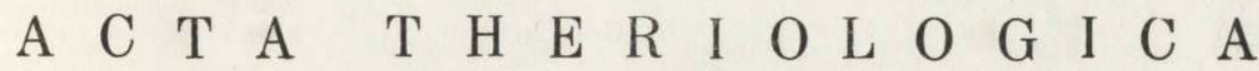 \\ VOL. XVI, 15: 213-220. \\ BIAŁOWIEŻA \\ August, 1971
}

\author{
Andrzej G Ó R E C K I
}

\section{Metabolism and Energy Budget in the Harvest Mouse*}

\author{
[With 1 Table \& 3 Figs.]
}

\begin{abstract}
The average daily metabolic rate $(A D M R)$ at $20^{\circ} \mathrm{C}$ and resting metabolic rate $(R M R)$ in the range of ambient temperatures from 0 to $30^{\circ} \mathrm{C}$ were determined in the harvest mouse. ADMR of the harvest mouse with the body weight of $8.7 \mathrm{~g}$ amounted to $7.57 \pm 1.91 \mathrm{ccm} \mathrm{O}_{2} / \mathrm{g} \mathrm{h}$ and the relationship between $A D M R$ and body weight $(W)$ is expressed by the equation: $A D M R=22.8 W-.53 . R M R$ was equal to $19.8 \mathrm{ccm} \mathrm{O_{2 } / g ~ h}$

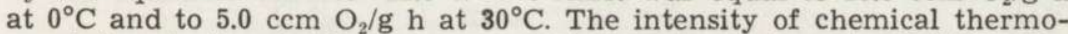
regulation in the studied range amounted to approximately $10 \% /{ }^{\circ} \mathrm{C}$. The daily energy budget $(D E B)$ of harvest mice computed from the data given above is illustrated by the following equations: $D E B$ kcal $/ \mathrm{g}$ day $=3.03 W-.50$ in summer, and $D E B=3.05 W^{-} .50$ in winter.
\end{abstract}

\section{INTRODUCTION}

The harvest mouse (Micromys minutus $\mathrm{Pallas}$, 1778) is one of the smallest European rodents. Its mean body weigth is around $8 \mathrm{~g}$ (K u bik, 1952). The body surface of such small harvest mouse has been estimated as $38 \mathrm{~cm}^{2}$. The body volume is equal to body weight, assuming that specific weight $=1$. Hence the ratio of surface to volume is in the harvest mouse very unfavourable and amounts to 4.9 , whereas in Apodemus flavicollis weighing $30 \mathrm{~g}$ such ratio is around 2.5. The European harvest mouse does not hibernate and is widely distributed in Palearctic regions where it occupies grassland ecosystems.

Despite their small size harvest mice may cause considerable losses in corn plantations, especially in the periods of mass occurrence ( $\mathrm{S} \mathrm{k} \mathrm{u}$ ratow ic z, 1957).

\section{MATERIAL AND METHODS}

During the experiments harvest mice were exposed to $12 \mathrm{hr}$ light rhythm and provided with food similar to the natural one (oat, wheat, carrot, water). The everage daily metabolic rate $(A D M R)$ was determined as oxygen consumption in

* This work was carried out under the small Mammal Project of the International Biological Programme in Poland. 
a Morrison respirometer (Morrison \& Grodziński, 1968) and expressed in $\mathrm{ccm} \mathrm{O}_{2} / \mathrm{g} \mathrm{h}$. The animals were kept in 91 chambers at $20^{\circ} \mathrm{C}$. The resting metabolic rate $(R M R)$ was determined at ambient temperatures $0,10,20$ and $30^{\circ} \mathrm{C}$ in a Kalabukhov-Skvortzov respirometer (Górecki, 1968). Daily metabolism was measured in $19^{1}$ ) mice, resting metabolism in 22 mice, all determinations were carried out in autumn and winter.

\section{RESULTS}

The thermoregulation curve of harvest mice is very steep and the absolute increase of oxygen consumption in the studied range of temperatures amounts to $298 \%$, or almost $10 \% /{ }^{\circ} \mathrm{C}$ (Fig. 1). This increase is highest at the lowest temperatures (from 0 to $10^{\circ} \mathrm{C}$ ) where it reeaches almost $15 \% /{ }^{\circ} \mathrm{C}$ (Fig. 1).

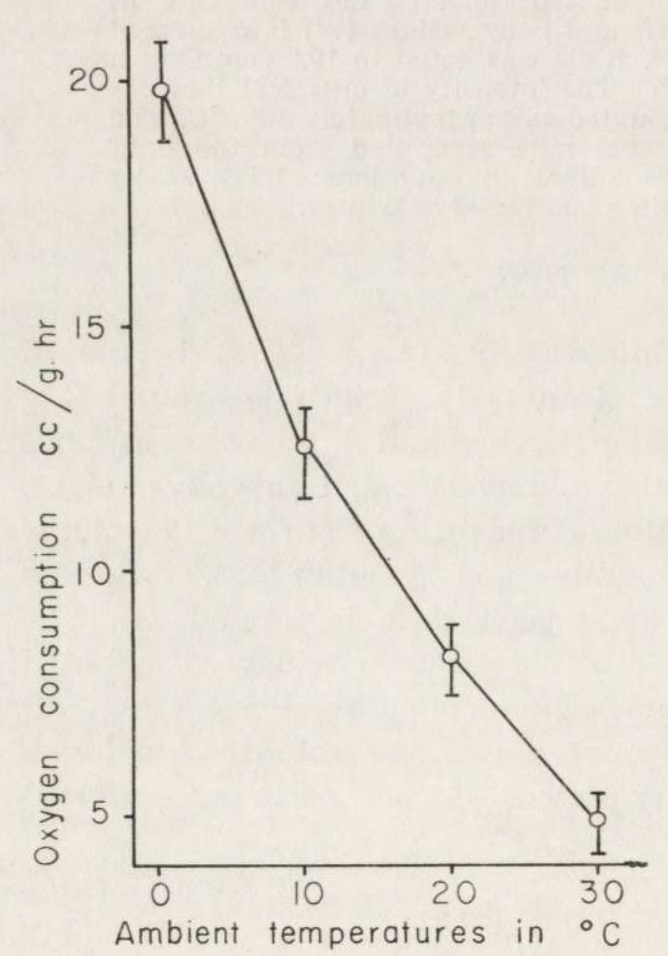

Fig. 1. Resting metabolic rate $(R M R)$ in the harvest mice, as a function of ambient temperature. Vertical lines represent the mean $\pm \mathrm{S}$. D.

$A D M R$ of harvest mice with the body weight (Avg. \pm S.D.) $8.71 \pm 2.60 \mathrm{~g}$ was equal to $7.57 \pm 1.91 \mathrm{ccm} \mathrm{O}_{2} / \mathrm{g} \mathrm{h}(C . V .=25.2 \%)$. Assuming $R Q=0.82$ this value amounts to $.87 \mathrm{kcal} / \mathrm{g}$ day.

1) Some of the animals derived from the Mammals Research Institute, Polish Academy of Sciences at Białowieża and the author is grateful for this generous help. 
The relationship between $A D M R$ and body weight $(W)$ in the range from 4.7 to $14.7 \mathrm{~g}$ (Fig. 2) is illustrated by the following equation:

$$
A D M R \mathrm{ccm} \mathrm{O} \mathrm{O}_{2} / \mathrm{g} \mathrm{h}=22.8 \mathrm{~W}^{-.53}
$$

The slope of this curve is very similar to those in other small rodents where the exponent $b$ oscillates around -.50 .

The daily rhythm of metabolism was polycyclic, close to the bimodal type, with two marked peaks in night hours (Fig. 3). When the periods of the highest and the lowest oxygen consumption during $24 \mathrm{~h}$ are compared it appears that the minimum metabolism is equal to 5.2 , and the maximum to $14.3 \mathrm{ccm} \mathrm{O}_{2} / \mathrm{g} \mathrm{h}$ (minimum : maximum ratio=2.75).

The influence of group effect on the $A D M R$ in harvest mice was also studied. For this purpose the metabolism of 4 animals kept together in the metabolic chamber at $20^{\circ} \mathrm{C}$ was estimated. It was found that metabolism of harvest mice in the group decreases by $13 \%$ on the average.

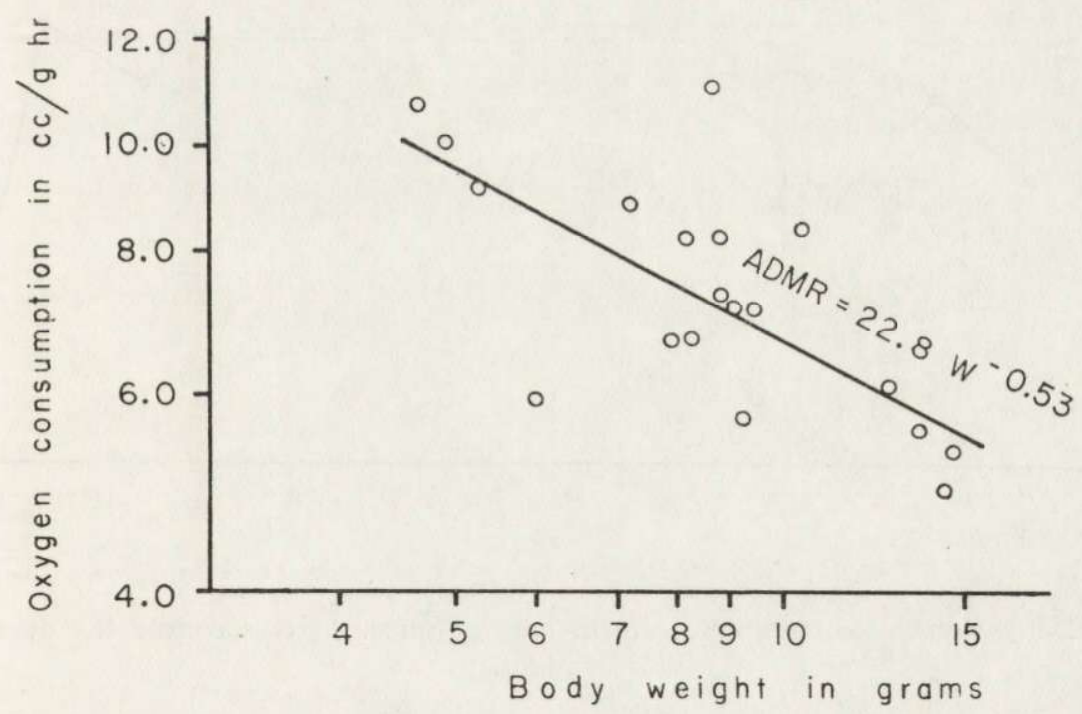

Fig. 2. Relationship between average daily metabolic rate $(A D M R)$ and body weight in harvest mice.

\section{DISCUSSION}

Metabolism of European harvest mice was investigated only by Smirnov (1957). $R M R$ determined by that author in winter is almost identical to the value found in the present study, e.g. in $20^{\circ} \mathrm{C}$ it differs only by $.36 \mathrm{ccm} \mathrm{O}_{2} / \mathrm{g} \mathrm{h}$, and in $10^{\circ} \mathrm{C}$ is equal in both cases to $12.5 \mathrm{ccm}$ 
$\mathrm{O}_{2} / \mathrm{g}$ h. This comparison is, however, not quite complete since $\mathrm{S} \mathrm{mir} \mathrm{nov}$ (l.c.) did not report body weight of examined individuals. Intensity of chemical thermoregulation determined by $\mathrm{Smirnov}$ (l.c.) in winter is slightly lower and amounts to $5 \% /{ }^{\circ} \mathrm{C}$. This is probably related to the fact that this autor investigated the temperature-metabolism curve only in the range from 10 to $28^{\circ} \mathrm{C}$.

Respirometric determinations of S mir nov (1957), and in the present study, are in agreement with the data obtained by $\mathrm{Hawkins}$ \& J e w ell (1962) from food consumption. The harvest mice of $7.2 \mathrm{~g}$ body

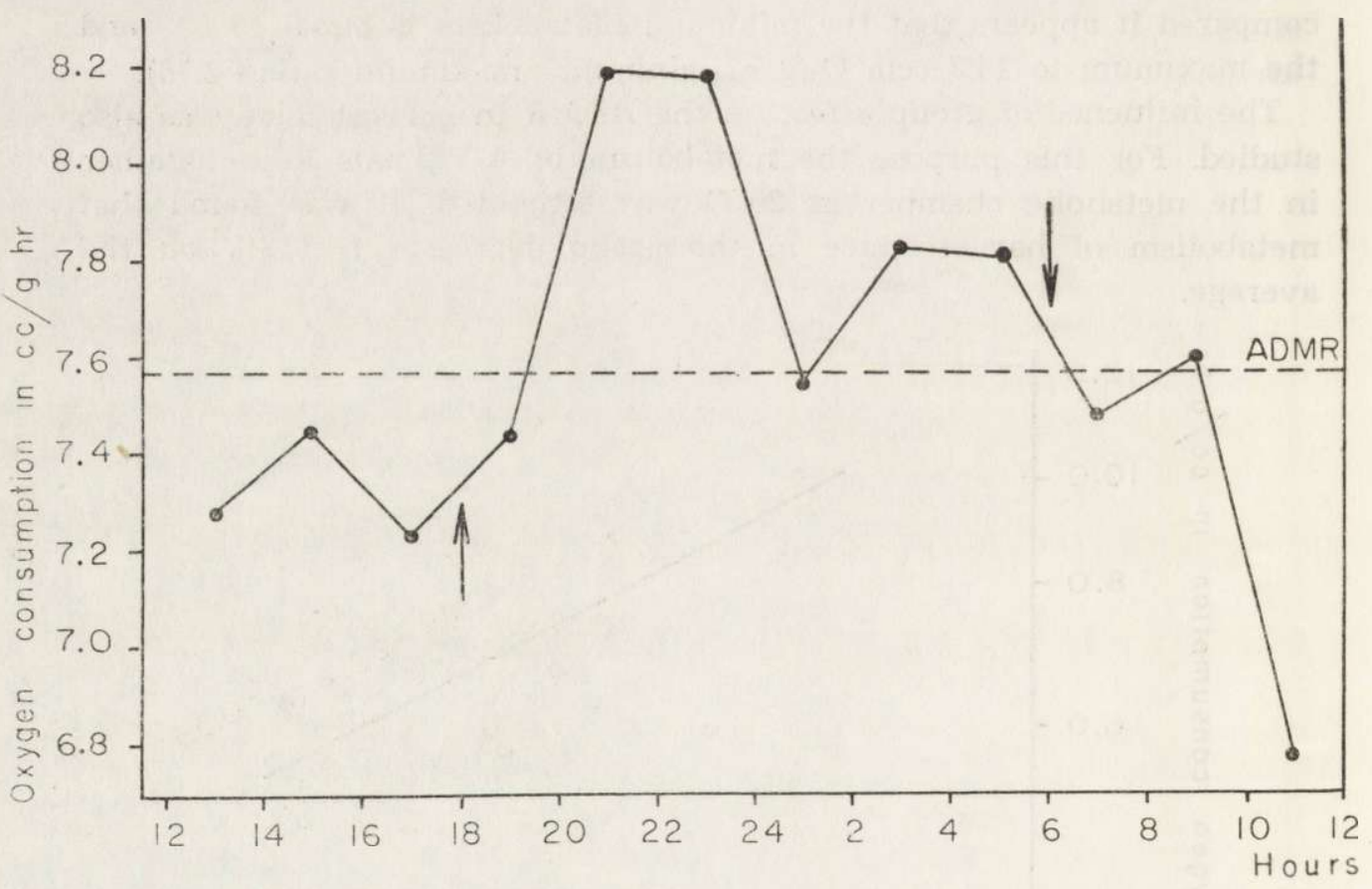

Fig. 3. Daily rhythm of metabolic rate in harvest mice. Arrows denote the duration of night.

weight consumed $.97 \mathrm{kcal} / \mathrm{g}$ day. When this value is reduced by approximately $10 \%$ to account for losses with faeces and urine the value of metabolizable energy is almost identical with the $A D M R$ in the present study.

Metabolism and energy budget of the American harvest mouse (Reithrodontomys megalotis $\mathrm{B}$ a i rd, 1858), which is similar in body size and ecology to M. minutus, was extensively studied by Pearson (1960). The $A D M R$ of this $9 \mathrm{~g}$ rodent determined at $18^{\circ} \mathrm{C}$ was slightly lower 
than value obtained in the present experiments and amounted to $6.5 \mathrm{ccm}$ $\mathrm{O}_{2} / \mathrm{g}$ h.

The ADMR of harvest mice (Micromys) in comparison with other mice (Apodemus) is significantly higher. This is clearly visible after computing $A D M R$ for metabolic unit of body weight: in $33 \mathrm{~g}$ Apodemus flavicollis this value amounts to $160 \mathrm{kcal} / \mathrm{kg} \cdot 75$ day (recalculated from G ębczyński, 1966), in $20 \mathrm{~g}$ A. agrarius to $218 \mathrm{kcal} / \mathrm{kg}^{75}$ day (G ó$\mathrm{recki}, 1969)$, and in the harvest mouse to $291 \mathrm{kcal} / \mathrm{kg} \cdot{ }^{75}$ day.

The determination of $A D M R$ and $R M R$ in $M$. minutus permits for the construction of the daily energy budget $(D E B)$ Grodzinski \& Górecki, 1967; Górecki ,1968, 1969) and expressing it as a function of body weight ( $\mathrm{H}$ ansson \& Grodzinski, 1970). The DEB is based on $A D M R$ which is related to body weight according to the function (1). The coefficient $b$ of this equation may be rounded to -.50 , since most small rodents show just such value (Grodziński, 1967; Hansson \& Grodzinski, 1970). The suitably fitted equation assumes the following form:

$$
A D M R \text { ccm } \mathrm{O}_{2} / \mathrm{g} \mathrm{h}=21.2 W^{-.50}
$$

The $A D M R$ measured at $20^{\circ} \mathrm{C}$ represents the value of energy requirements of the harvest mouse in the temperature close to that in the nest, since its nest, both in winter and summer, shows good insulatory properties (S mirnov, 1957).

The daily activity of the harvest mouse was investigated by many authors (Smirnov, 1957a; Saint Girons, 1966; Gelmroth, 1969). In summer the harvest mouse is active for $4-6$ hours during the day, most of this time being spent out-of-the-nest. For calculating the budget it was assumed that this time is equal in summer to $5 \mathrm{~h}$, and in winter is probably shorter.

In summer the temperature in the natural habitat of harvest mice amounts in Poland to $15^{\circ} \mathrm{C}$ on the average, or differs by $5^{\circ} \mathrm{C}$ from the temperature in which $A D M R$ was measured. In this range the intensity of thermoregulation calculated from $R M R$ is rather high and amounts to $8.61 \% /{ }^{\circ} \mathrm{C}$ (Fig. 1), hence the correction for heat production for out-of-the-nest thermoregulation is equal to: $20 \%$ of the day $\left(5^{\circ} \mathrm{C} \times 8.61 \% /{ }^{\circ} \mathrm{C}\right)$ : $100=8.6 \%$. The summer $D E B$ is encumbered also by the costs of reproduction. K u bik (1952) reported that the number of females in the population of harvest mice in the Białowieża National Park amounts to approximately $44 \%$. Assuming that half of them participates in the reproduction this constitutes $22 \%$ of the whole population. Both pregnancy and lactation are associated with great energy expenses for the female because she produces a large litter (mean weight $4.8 \mathrm{~g}$ ), and 
nurses the newborns for 16 days (S m ir nov, 1959; 1959a). Hence the increase of energy requirements in the harvest mouse during reproduction is probably not lower than in voles, in which it amounts to $58 \%$ (Kaczmarski, 1966), or to $81.5 \%$ (Trojan \& Wojciechow$\mathrm{ska}, 1967)$ or to $82.5 \%$ ( $\mathrm{M} \mathrm{ig} \mathrm{u} \mathrm{la}, 1969)$. Assuming the mean increase of energy expenses in the reproducing female as equal to $70 \%$, the daily energy requirement for an individual in the harvest mouse population should be increased by $15.5 \%$. It may be mentioned that in calculating additional energy requirements for reproduction value of production (newborns with foetal membranes etc $=5.8 \mathrm{kcal}$ approximately) has already been subtracted.

These two corrections, for heat production for out-of-the-nest thermoregulation and for reproduction, amount jointly to $24.1 \%$ in summer. They may be added to function (2) by multiplying it by the factor=1.241. Such function for the summer period is shown in Table 1.

Table 1

Comparison of the daily energy budget of harvest mice in summer and winter.

\begin{tabular}{|l|c|c|}
\hline \multicolumn{1}{|c|}{ DEB } & Summer & Winter \\
\hline $\mathrm{ccm} \mathrm{O}_{2} / \mathrm{g} \mathrm{hr}$ & $26.3 \mathrm{~W}^{-.50}$ & $26.5 \mathrm{~W}^{-.50}$ \\
$\mathrm{kcal} / \mathrm{g}$ day & $3.03 \mathrm{~W}^{-.50}$ & $3.05 \mathrm{~W}^{-.50}$ \\
$\mathrm{kcal} /$ animal day & $3.03 \mathrm{~W}^{.50}$ & $3.05 \mathrm{~W}^{.50}$ \\
\hline
\end{tabular}

The whole budget may be easily recalculated for calories by multiplying it by the caloric equivalent of $1 \mathrm{ccm} \mathrm{O}_{2}=.0048 \mathrm{kcal}$ and by 24 hours, per unit of body weight, or the whole animal (Table 1).

In analogous manner the winter $D E B$ may be estimated. Of course in winter the costs for the out-of-the-nest thermoregulation will be increased, but the budget will not be encumbered by costs of reproduction. The temperature under snow, or in straw-stacks where harvest mice are active ( $\mathrm{S} \mathrm{mirnov}, 1957,1957 \mathrm{a})$ is close to $0^{\circ} \mathrm{C}$. The intensity of thermoregulation calculated from $R M R$ amounts in this region up to $12.1 \% /{ }^{\circ} \mathrm{C}$. It may be assumed that activity period on a winter day is around $2-3$ hours. Hence the additional heat production for thermoregulation amounts in this time to $25.2 \%$ (multiplying factor $=1.252$ ) (Table 1). As shown in this Table the winter budget is very similar to the summer one.

When the mean budget for summer and winter $(a=3.04)$ is solved for the harvest mouse of $8 \mathrm{~g}$ body weight the following values are obtained: 
$1.07 \mathrm{kcal} / \mathrm{g}$ day, or $8.60 \mathrm{kcal} / \mathrm{animal}$ day. Hence the daily costs of maintenance of the small harvest mouse are only slightly lower than the $D E B$ of $20 \mathrm{~g}$ weighing vole or mouse (G ór e cki, 1968; 1969). This depends mainly on the high heat production for thermoregulation.

\section{REFERENCES}

1. Gelmroth K. G., 1969: Die Aktivitätsmuster von Gelbhalsmäusen (Apodemus flavicollis) und Zwergmäusen (Micromys minutus) aus dem Raume Kiel. Säugetier., 34, 6: 371-375.

2. Gębczyński M., 1966: The daily energy requirement of the yellownecked field mouse in different seasons. Acta theriol., 11, 17: 391-398.

3. Górecki A., 1968: Kalabukhov-Skvortzov respirometer and RMR measurement. [In: "Methods of Ecological Bioenergetics«, Eds W. Grodziński \& R. Klekowski]. Państw. Wyd. Nauk.: 165-171. Warszawa - Kraków.

4. Górecki A., 1968: Metabolic rate and energy budget in the bank vole. Acta theriol., 13, 20: 341-365.

5. Górecki A., 1969: Metabolic rate and energy budget of the striped field mouse. Acta theriol., 14, 14: 181-190.

6. Grodziński W., 1967: Daily metabolism rate and body size of common voles (Microtus arvalis Pall.). Small Mamm. Newsl. 1, 3: 5-6.

7. Grodziński W. \& Górecki A., 1967: Daily energy budgets of small rodents. [In: „Secondary Productivity of Terrestrial Ecosystems«, Ed. K. Petrusewicz]. Państw. Wyd. Nauk.: 295-314. Warszawa - Kraków.

8. Hansson L. \& Grodziński W., 1970: Bioenergetic parameters of the field vole Microtus agrestis L. Oikos, 21, 1: 76-82.

9. Hawkins A. E. \& J e we 11 P. A., 1962: Food consumption and energy requirements of captive british shrews and mole. Proc. Zool. Soc. London., 138,1: $137-155$.

10. Kaczmarski F., 1966: Bioenergetics of pregnancy and lactation in the bank vole. Acta theriol., 11, 19: 409-417.

11. Kubik J., 1952: Micromys minutus Pa11. w Białowieskim Parku Narodowym. Annls Univ. M. Curie - S k ło d ow s k a C, 7, 7: 449-496.

12. Migula P., 1969: Bioenergetics of pregnancy nad lactation in the European common vole (Microtus arvalis (P a 11 a s, 1779). Acta theriol., 14, 13: 167-179.

13. Morrison P. R. \& Grodziński W., 1968: Morrison respirometer and determination of ADMR. [In: "Methods of Ecological Bioenergetics«, Eds W. Grodziński \& R. Klekowski]: 153-163. Warszawa - Kraków.

14. Pearson O. P., 1960: The oxygen consumption and bioenergetics of harvest mice. Physiol. Zöol., 33, 2: 152-160.

15. Saint Girons M. C., 1966: Le rythme circadien de l'activité chez les mammiferes holarctiques. Mém. Mus. Nation. Hist. Natur., A, 40, 3: 7-187.

16. Skuratowicz W., 1957: Uwagi o pojawach gryzoni polnych w Polsce w latach 1945-1955. Ekol. pol., B, 3, 1: 3-16.

17. Smirnov P. K., 1957: Osobennosti teploobmena u myši-maljutki (Micromys minutus Pa 11.). Dokl. Akad. Nauk SSSR. 117, 4: 717-719.

18. Smirnov P. K., 1957a: Sutocnyj cikl aktivnosti u myši-maljutk (Micromys minutus Pa 11.). Dokl. Akad. Nauk SSSR. 117, 5: 892-893. 
19. Smirnov P. K., 1959: O postembrionalnom razviti myši-maljutki (Micromys minutus P a 11.). Nauč. Dokl. Vysš. Šk., Biol. Nauki, 3: 76-78.

20. Smirnov P. K., 1959a: O biologii rozmnoženija myši-maljutki (Micromys minutus $\mathrm{P}$ a 11.). Nauč. Dokl. Vysš. Šk., Biol. Nauki, 1: 40-42.

21. Trojan P. \& Wojciechowska B., 1967: Resting metabolism rate during pregnancy and lactation in the European common vole - Microtus arvalis (P a 11.). Ekol. pol. A, 15, 44: 811-817.

Accepted, March 16, 1971.

Department of Animal Genetics and Organic Evolution, Jagiellonian University,

Kraków 2, Krupnicza 50, Poland.

\section{Andrzej GÓRECKI}

\section{METABOLIZM I BUDŻET ENERGETYCZNY BADYLARKI}

\section{Streszczenie}

U badylarek - Micromys minutus (Pallas, 1778), $(\mathrm{N}=22)$ mierzono średni metabolizm dobowy $(A D M R)$ w temperaturze $20^{\circ} \mathrm{C}$ i metabolizm spoczynkowy $(R M R)$ w $0,10,20$ i $30^{\circ} \mathrm{C}$.

$A D M R$ badylarki o średnim ciężarze ciała $8,7 \pm 2,6 \mathrm{~g}$ wynosił $7,57 \pm 1,91 \mathrm{~cm}^{3}$ $\mathrm{O}_{2} / \mathrm{g}$ godz. Zależność $A D M R$ od ciężaru ciała wyraża równanie: $A D M R \quad \mathrm{~cm}^{3} \mathrm{O}_{2} / \mathrm{g}$ godz. $=22,8 W-0,53$ (Fig. 2). Dobowy rytm metabolizmu badylarek posiadał wzorzec dwudzielny, głównie nocny (Fig. 3).

$R M R$ w temperaturze $0^{\circ} \mathrm{C}$ wynosił $19,8 \mathrm{~cm}^{3} \mathrm{O}_{2} / \mathrm{g}$ godz., a w temperaturze $30^{\circ} \mathrm{C}-$ $5,0 \mathrm{~cm}^{3} \mathrm{O}_{2} / \mathrm{g}$ godz. (Fig. 3). Intensywność termoregulacji chemicznej $\mathrm{w}$ całym badanym zakresie była bardzo wysoka, wynosiła około $10 \% /{ }^{\circ} \mathrm{C}$, a w najniższych badanych temperaturach aż $15 \% /{ }^{\circ} \mathrm{C}$ (Fig. 3).

Wyliczony $\mathrm{z}$ powyższych danych dobowy budżet energetyczny (DEB) badylarek ilustrują równania: w lecie $D E B \mathrm{kcal} / \mathrm{g}$ doba $=3.03 \mathrm{~W}-0,50$, i w zimie $D E B \mathrm{kcal} / \mathrm{g}$ dobę $=3.05 \mathrm{~W}-0,50$. Jeżeli średni budżet dla lata i zimy rozwiązać dla $8 \mathrm{~g}$ badylarki, to otrzyma się następujące wartości: $1,07 \mathrm{kcal} / \mathrm{g}$ na dobę, lub $8,60 \mathrm{kcal} / \mathrm{zwierzę} \mathrm{na}$ dobę.

Taka wysoka wartość dobowego budżetu energetycznego u badylarki wiąże się głównie z wysoką produkcją ciepła na termoregulację, co wynika z bardzo niekorzystnego stosunku powierzchni do objętości ciała tych małych gryzoni. 